\title{
STRATEGI PEMASARAN PAKET WISATA TIRTAYATRA KE INDIA PADA MELATI TOURS
}

\author{
Kadek Bagus Gede Jelantik ${ }^{1}$, N.M.S. Wijaya ${ }^{2}$, Putu Agus Wikanatha Sagita ${ }^{3}$ \\ Email : bagusjelantik18@gmail.com ${ }^{1}$,mdsofiawij@gmail.com², aguswika@unud.ac.id ${ }^{3}$ \\ ${ }^{1,2,3}$ Program Studi Industri Perjalanan Wisata, Fakultas Pariwisata, Universitas Udayana
}

\begin{abstract}
Many travel agents facilitate the interest of tourists, especially Balinese people to do Tirtayatra to India. One of them is Melati Tours as a travel agent providing package tours of Tirtayatra to India. This study was conducted to find out the right marketing strategy of Tirtayatra tour packages to India at Melati Tours. The data analysis technique used are internal environment/IFAS using Marketing Mix 7P analysis as an internal factors and external environment/EFAS using market analysis, competitor analysis, government analysis, technology analysis, economic analysis, social-cultural analysis, environmental analysis and SWOT analysis. The type of data used is quantitative and qualitative data, primary and secondary data. Data collection techniques by observation, interviews, study of literature, documentation and distribution of external internal questionnaires to 100 tourist who bought Tirtayatra tour packages at Melati Tours and to Melati Tours owners and Tourism Academics. Data analysis technique used is mix methods. This study used 18 internal sub-indicators and 8 external sub-indicators and obtained 11 strength factors, 7 weakness factors, 5 opportunity factors and 3 threat factors. Based on the results of data processing on external internal factors/IFAS EFAS, the total value of IFAS is 2,65 and EFAS is 2,20, this indicating the position of the Tirtayatra tour package on Melati Tours in this study is in cell VIII, namely Growth Strategy and Conglomerate Diversification. Melati Tours in marketing Tirtayatra tour packages to India requires a growth strategy through more strategic pressure on financial synergy rather than product marketing strategy for products and prices balance.
\end{abstract}

Abstrak: Banyak biro perjalanan memfasilitasi minat wisatawan khususnya orang Bali untuk melakukan Tirtayatra ke India. Salah satunya adalah Melati Tours sebagai biro perjalanan penyedia paket wisata tirtayatra ke India. Tujuan penelitian ini adalah untuk mengetahui strategi pemasaran yang tepat untuk memasarkan paket wisata Tirtayatra ke India pada Melati Tours. Teknik analisis data yang digunakan adalah penjabaran lingkungan internal/IFAS dengan menggunakan analisis Marketing Mix 7P sebagai faktor internal, sedangkan penjabaran lingkungan eksternal/EFAS dengan menggunakan analisis pasar, analisis kompetitor, analisis pemerintah, analisis teknologi, analisis ekonomi, analisis sosial budaya dan analisis lingkungan serta analisis SWOT. Jenis data yang digunakan adalah data kuantitaif dan kualitatif, data primer dan sekunder. Teknik pengumpulan data dengan cara observasi, wawancara, studi kepustakaan, dokumentasi serta penyebaran kuesioner internal eksternal kepada 100 wisatawan yang membeli paket wisata Tirtayatra ke India pada Melati Tours serta kepada pihak Melati Tours dan Akademisi Pariwisata yang berkompeten dibidang pemasaran. Teknik analisis data yang digunakan adalah mix methods. Hasil penelitian menggunakan 18 sub indikator lingkungan internal dan 8 sub indikator lingkungan eksternal, maka diperoleh 11 faktor kekuatan, 7 faktor kelemahan, 5 faktor peluang dan 3 faktor ancaman. Berdasarkan hasil pengolahan data terhadap faktor internal eksternal/IFAS EFAS diketahui total nilai IFAS adalah 2,65 dan total nilai EFAS adalah 2,20 sehingga menunjukkan posisi paket wisata Tirtayatra ke India berada pada sel VIII yaitu Strategi Growth dan Diversifikasi Konglomerat. Melati Tours dalam memasarkan paket wisata Tirtayatra ke India memerlukan strategi pertumbuhan melalui tekanan strategi lebih pada sinergi finansial daripada sinergi pemasaran produk untuk keseimbangan produk dan harga.

Keywords: marketing strategy, spiritual tourism, travel agent. 


\section{PENDAHULUAN}

Bali sangat dikenal dengan pariwisata budaya, keindahan alam, keunikan budaya, adat istiadat dan tradisi yang masih kental dalam kehidupan masyarakat Bali sehari - hari. Pendapat yang menyatakan bahwa orang Bali tidak menyukai liburan namun lebih senang mengeluarkan uang untuk kegiatan upacara keagamaan daripada tamasya saat ini mulai terbantahkan (Soethama, 2011). Salah satu aktivitas wisata yang masih menjadi ikon Bali adalah wisata spiritual, dimana permintaan untuk melakukan aktivitas wisata spiritual di Bali mengambil pasar yang cukup dipertimbangkan, dengan semakin banyaknya permintaan atas kegiatan wisata spiritual saat ini di Bali, maka semakin banyak pula BPW yang ingin memfasilitasi mereka.

Wisata spiritual atau yang dikenal dengan istilah tirtayatra memiliki tujuan untuk memenuhi kebutuhan rohani manusia untuk memperkuat iman dengan mendatangi tempat tempat yang dianggap memiliki nilai religius. Wisata spiritual merupakan salah satu fenomena yang saat ini mulai tumbuh dikalangan masyarakat, hal itu dibuktikan dengan adanya aktifitas atau kegiatan yang dikaitkan dengan wisata spiritual seperti tirtayatra. Dibeberapa kelompok masyarakat, wisata spiritual ini sering dijadikan sebagai kegiatan rutin baik bulanan, tahunan dan sebagainya. Oleh karena itu, bukan hanya kesehatan pikiran saja yang didapatkan melalui wisata spiritual atau tirtayatra akan tetapi juga mendapatkan pahala dengan memaknai wisata spiritual sebagai ibadah untuk meningkatkan keimanan.

Pengertian tentang wisata spiritual juga dikemukakan oleh Nyoman S. Pendit (1994) dalam bukunya yang berjudul Ilmu Pariwisata, menjelaskan tentang pengertian wisata spiritual atau tirtayatra yaitu jenis wisata yang banyak dikaitkan dengan agama, adat istiadat dan kepercayaan umat atau kelompok dalam masyarakat, selanjutnya pengertian wisata spiritual menurut Oka A. Yoeti (1985) yang menyatakan bahwa wisata spiritual atau tirtayatra yaitu jenis wisata dimana tujuan perjalanam yang dilakukan adalah untuk melihat atau menyaksikan upacara keagamaan dan juga beribadah disana.

Paket wisata tirtayatra ke India merupakan sebuah paket wisata yang dirancang sebagai wisata keagamaan (perjalanan suci) Agama Hindu ke India, yang dimana didalamnya menyajikan atraksi wisata persembahyangan, mengunjungi tempat suci Agama Hindu yang ada di India, melihat kegiatan keagamaan Agama Hindu yang ada pada tempat suci di India serta menikmati keindahan alam dan budaya yang ada di India. Paket wisata tirtyatra ke India sama seperti paket wisata pada umumnya yang menyediakan fasilitas pendukung seperti penginapan/hotel, transportasi, tiket pesawat, jadwal makan, visa, dan passport yang dibantu agen perjalanan yang dipilih. Berdasarkan hasil observasi yang telah dilakukan, terdapat 5 Travel Agent yang paling tinggi tingkat penjualannya. Dengan perbandingan perkembangan jumlah keberangkatan wisatawan yang melakukan tirtayatra ke India pada 5 travel agent selama 5 tahun terakhir, diketahui bahwa Melati Tours memiliki jumlah keberangkatan tirtayatra ke India paling sedikit diantara 4 travel agent yang lain. Oleh karena itu Melati Tours diharapkan mampu mengatasi hal tersebut serta dapat memenangkan persaingan, maka dari itu perlu dilakukannya strategi pemasaran guna memenangkan persaingan diantara agen perjalanan yang menyediakan paket wisata tirtayatra ke India seperti memperbaiki paket wisata yang telah ditetapkan salah satunya dengan cara mengetahui bagaimana variasi paket wisata yang sebenarnya diinginkan oleh wisatawan dengan harga yang masih terjangkau untuk mereka.

Tingginya minat atau tujuan wisatawan untuk melakukan tirtayatra ke India sehingga banyak BPW yang ingin memfasilitasi perjalanan tirtayatra tersebut salah satunya adalah Melati Tours. Maka penelitian ini dilakukan untuk mengetahui strategi pemasaran yang tepat dalam paket wisata tirtayatra pada Melati Tours yang dapat dikembangkan dan menjadi paket yang berbeda dari BPW lainnya.

\section{METODE}

Studi ini dilakukan di Melati Tours yang berlamatkan di Jl. Melati No.61, Dangin Puri Kangin, Kec. Denpasar Timur, Kota Denpasar. Lokasi ini dipilih karena Melati Tours merupakan salah satu biro perjalanan yang mengkemas dan menjual paket wisata tirtayatra ke India.

Variabel yang digunakan adalah Bauran Pemasaran (Marketing Mix) 7P dalam studi ini sebagai lingkungan internal/IFAS yang terdiri dari indikator Product, Price, Place, Promotion, People, Physical Evidence dan 
Process, peneliti akan mencari tahu bagaimana gambaran mengenai lingkungan pemasaran internal paket wisata tirtayatra ke India pada Melati Tours dengan indikator dari masing masing variabel tersebut sebagai kekuatan dan kelemahan yang dimiliki paket wisata tirtayatra ke India pada Melati Tours. Sedangkan indikator pasar, kompetitor, pemerintah, teknologi dan ekonomi sebagai lingkungan pemasaran eksternal/EFAS dalam studi ini dengan sub indikator dari masing - masing indikator tersebut. Peneliti akan mencari tahu bagaimana gambaran lingkungan pemasaran eksternal dari paket wisata tirtayatra ke India pada Melati Tours sehingga diketahui peluang dan ancaman yang dihadapi oleh Melati Tours dalam memasarkan paket wisata tirtayatra ke India.

Teknik pengumpulan data dilakukan dengan metode observasi dengan mengamati langsung, kemudian metode wawancara dengan informan pangkal adalah Direktur dan Wakil Direktur Melati Tours sedangkan informan kunci dalam studi ini adalah bagian Accounting dan Ticketing \&Tour Melati Tours, selanjutnya adalah dengan metode studi kepustakaan dengan melihat telaah penelitian sebelumnya yang relevan sebagai acuan dan dengan metode dokumentasi dengan pengambilan foto dokumentasi pada saat melakukan penelitian.

Metode kuesioner juga digunakan dalam studi ini kepada 100 orang responden atau wisatawan yang membeli paket wisata tirtayatra ke India pada Melati Tours yang akan menjawab lingkungan pemasaran internal dan 10 orang responden yaitu pemilik dan karyawan Melati Tours dan 5 orang Akademisi Pariwisata yang berkompeten dibidang pemasaran yang akan menjawab lingkungan pemasaran eksternal dengan menggunakan teknik Skala Likert, untuk skor 1 menyatakan sangat tidak setuju sampai dengan skor 4 yang menyatakan sangat setuju, sehingga dapat dimasukkan kedalam kreteria hasil analisis untuk mengetahui rentang interval nilai terhadap masing - masing pernyataan yang telah dirancang dalam kuesioner pada studi ini (Kusmayadi, 2000).

Mix Methods digunakan pada studi ini. Metode ini dilakukan dengan menganalisis faktor lingkungan pemasaran internal dan eksternal/IFAS EFAS dengan menyebarkan kuesioner kepada wisatawan yang membeli paket wisata tirtayatra ke India pada Melati
Tours selanjutnya adalah kepada pemilik dan karyawan Melati Tours serta kepada 5 orang Akademisi Pariwisata yang berkompeten dibidang pemasaran.

\section{HASIL DAN PEMBAHASAN \\ Gambaran Umum Melati Tours}

Melati Tours atau PT. Saka Melati Wisata bertempat di Jl. Melati No.61 Denpasar, Bali yang didirikan oleh Ir. Ida Bagus Surya Sanjaya pada tanggal 22 Desember 2010 dengan dilengkapi Akta Notaris dan dilengkapi dengan ijin Legalitas Usaha.

Melati Tours mampu memberangkatkan wisatawan untuk tirtayatra ke India rata - rata sebanyak 15 orang setiap bulannya tetapi juga mengalami penurunan keberangkatan wisatawan setiap bulannya dikarenakan persaingan dengan travel agent lain yang juga menyediakan paket wisata tirtayatra ke India.

\section{Karakteristik Wisatawan Yang Membeli Paket Wisata Tirtayatra Ke India Pada Melati Tours}

Berdasarkan hasil studi ini, karakteristik wisatawan yang membeli paket wisata tirtayatra ke India yaitu berkewarganegaraan Indonesia dikarenakan wisatawan yang membeli paket wisata tirtayatra ke India pada Melati Tours adalah Orang Bali atau masyarakat lokal Bali yang ingin melaksanakan tiryatra ke India dengan persentase $100 \%$.

Wisatawan perempuan paling mendominasi daripada wisatawan laki - laki dalam studi ini. Wisatawan perempuan sebanyak $53 \%$ dan wisatawan laki laki sebanyak $47 \%$.

Berdasarkan umur wisatawan, wisatawan umur 30 - 40 Tahun mencapai $21 \%$, wisatawan umur 41 - 50 mencapai $56 \%$, kemudian wisatawan umur 51 - 60 Tahun mencapai $17 \%$ dan wisatawan umur 61 - 70 Tahun mencapai 6\%. Apabila dilihat dari jumlah persentasenya yaitu wisatawan berumur 41 - 50 Tahun lebih dominan membeli paket wisata tirtayatra ke India pada Melati Tours.

Selanjutnya berdasarkan pekerjaan wisatawan, wiraswasta $49 \%$, swasta $34 \%$ dan PNS 17\%. Apabila dilihat dari jumlah persentasenya yaitu wisatawan berumur dengan pekerjaan wiraswasta yang lebih dominan membeli paket wisata tirtayatra ke India pada Melati Tours.

Berdasarkan pendidikannya, wisatawan dengan pendidikan SD $0, \mathrm{SMP} /$ Sederajat $5 \%$, 
SMA/Sederajat 47\%, S1 34\% dan S2 $14 \%$. Apabila dilihat dari jumlah persentasenya yaitu wisatawan dengan pendidikan SMA/Sederajat lebih dominan membeli paket wisata tirtayatra ke India pada Melati Tours.

Wisatawan mengetahui Melati Tours melalui sosial media/internet $21 \%$, melalui website $16 \%$, melalui teman $52 \%$ dan melalui iklan(brosur) $11 \%$. Apabila dilihat dari jumlah persentasenya lebih dominan mengetahui melalui teman mengenai Melati Tours.

Wisatawan mengetahui paket wisata tirtayatra Melati Tours melalui sosial media/internet $17 \%$, melalui website $13 \%$, melalui teman $52 \%$ dan melalui iklan(brosur) $18 \%$. Apabila dilihat dari jumlah persentasenya lebih dominan wisatawan mengetahui paket wisata tirtayatra ke India pada Melati Tours melalui teman.

Berdasarkan berapa kali membeli paket wisata tirtayatra Melati Tours yaitu pertama kali 23\%, jarang (2-4kali) 71\%, cukup sering (5-7kali) 6\% dan sering (lebih dari 10kali) 0 . Apabila dilihat dari jumlah persentasenya yaitu wisatawan lebih dominan membeli paket wisata tirtayatra ke India pada Melati Tours adalah jarang (2-4kali).

Wisatawan menggunakan jasa Melati Tours dengan keluarga $7 \%$, dengan teman $11 \%$, dengan pasangan 0 dan dengan forum/organisasi $82 \%$. Apabila dilihat dari jumlah persentasenya yaitu wisatawan lebih dominan menggunakan jasa Melati Tours dengan forum/organisasi.

\section{Kondisi Lingkungan Internal Paket Wisata Tirtayatra ke India pada Melati Tours}

Berdasarkan hasil studi kondisi lingkungan internal paket wisata tirtayatra ke India pada Melati Tours, digunakan variabel dan indikator dari bauran pemasaran (Marketing Mix) 7P yang mencangkup Product, Price, Place, Promotion, People, Physical Evidence dan Process yang merupakan hasil dari penyebaran kuesioner yang telah diisi oleh 100 wisatawan adalah untuk mengetahui kekuatan dan kelemahan paket wisata tirtayatra ke India pada Melati Tours. Dalam studi ini menggunakan 18 sub indikator lingkungan internal, berdasarkan hasil pengolahan data yang telah dilakukan peneliti, terdapat 11 sub indikator internal yang menjadi kekuatan yakni (1) Kebersihan kantor Melati Tours (2) Proses memberikan informasi yang lengkap mengenai paket wisata tirtayatara ke India (3) Pelayanan pemandu wisata dalam kegiatan tirtayatra ke India (4) Promosi melalui penawaran menarik/potongan harga pada paket wisata tirtayatra ke India pada Melati Tours (5) Kebersihan dan kenyamanan transportasi yang digunakan (6) Proses pembelian paket wisata tirtayatra ke India (7) Kebersihan dan kerapian seragam pemandu wisata dan karyawam Melati Tours (8) Keramahan tamahan karyawan di Melati Tours dalam melayani (9) Pengetahuan pemandu wisata dan karyawan mengenai informasi paket wisata tirtayatra ke India pada Melati Tours (10) Lokasi Melati Tours strategis (11) Promosi paket wisata tirtayatra ke India melalui website Melati Tours. Sedangkan sub indikator internal yang menjadi kelemahan adalah 7 sub indikator yakni (1) Variasi daya tarik wisata yang dikunjungi dalam paket wisata tirtayatra ke India (2) Kesesuaian harga yang ditawarkan dengan kualitas paket wisata yang diberikan (3) Promosi paket wisata tirtayatra ke India melalui media Bali Tourist Channnel (4) Penjualan paket wisata melalui website (5) Ketersediaan fasilitas yang memadai seperti ruang tunggu yang nyaman pada Melati Tours (6) Promosi paket wisata tirtayatra ke India melalui Sosial Media (Facebook, Instagram, Twitter, dan sebagainya) (7) Harga paket wisata tirtayatra ke India pada Melati Tours. Selanjutnya kekuatan dan kelemahan yang dimiliki paket wisata tirtayatra ke India pada Melati Tours akan dimasukkan kedalam analisi SWOT.

\section{Kondisi Lingkungan Eksternal Paket Wisata Tirtayatra ke India pada Melati Tours}

Berdasarkan hasil studi lingkungan pemasaran ekstenal Pasar Seni Guwang, digunakan indikator pasar, kompetitor, pemerintah, teknologi dan ekonomi dengan masing - masing sub indikator didalamnya yang merupakan segala kejadian diluar Melati Tours dalam memasarkan paket wisata tirtayatra ke India berpotensi menjadi peluang maupun ancaman sebagai gambaran untuk paket wisata tirtayatra ke India pada Melati Tours agar terus dapat bersaing dengan menyesuaikan strategi yang diterapkan sehingga mampu bertahan. Hasil penyebarann kuesioner yang telah diisi oleh pemilik dan karyawan Melati Tours yang berjumlah 5 orang serta 5 orang Akademisi Pariwisata yang berkompeten di bidang pemasaran. Studi ini menggunakan 8 sub indikator lingkungan eksternal, dari hasil pengolahan data yang telah dilakukan peneliti, 
terdapat 8 sub indikator eksternal yang menjadi peluang yakni (1) Adanya trend tirtayatra ke India yang terus berkembang (2) Kebijakan pemerintah dalam memudahkan proses keberangkatan ke luar negeri khususnya ke India (3) Semakin banyaknya BPW yang menjual paket wisata tirtayatra ke India di Bali (4) Perkembangan alat komunikasi (5) Kemajuan media internet dalam memasarkan produk tirtayatra ke India. Sedangkan sub indikator yang menjadi ancaman adalah 3 sub indikator yakni (1) Nilai tukar rupiah melemah (2) Krisis ekonomi global (3) Semakin banyaknya online travel agent yang menjual paket wisata tirtayatra ke India. Selanjutnya peluang dan ancaman terhadap paket wisata tirtayatra ke India pada Melati Tours akan dimasukkan kedalam analisis SWOT.

Dalam menentukan strategi pemasaran yang dapat dilakukan oleh Melati Tours dalam memasarkan paket wisata tirtayatra ke India yaitu dengan menganalisis faktor lingkungan internal (Internal Factor Analysis Summary) atau IFAS dari hasil kuesioner yang dibagikan kepada 100 wisatawan yang membeli paket wisata tirtayatra ke India pada Melati Tours pada tabel 1 .

Tabel 1

Bobot, Rating dan Skor IFAS Paket Wisata Tirtayatra ke India pada Melati Tours

\begin{tabular}{|c|c|c|c|c|}
\hline \multicolumn{2}{|c|}{ Faktor } & Bobot & Rating & Skor \\
\hline \multicolumn{5}{|c|}{ Kekuatan : } \\
\hline 1 & $\begin{array}{l}\text { Kebersihan kantor Melati } \\
\text { Tours }\end{array}$ & 0,05 & 3,15 & 0,15 \\
\hline 2 & $\begin{array}{l}\text { Proses memberikan } \\
\text { informasi yang lengkap } \\
\text { mengenai paket } \\
\text { wisata tirtayatara ke India }\end{array}$ & 0,06 & 3,11 & 0,18 \\
\hline 3 & $\begin{array}{l}\text { Pelayanan pemandu } \\
\text { wisata dalam kegiatan } \\
\text { tirtayatra ke India }\end{array}$ & 0,07 & 3,06 & 0,21 \\
\hline 4 & $\begin{array}{l}\text { Promosi penawaran } \\
\text { menarik/potongan harga } \\
\text { pada paket wisata } \\
\text { tirtayatra ke India }\end{array}$ & 0,06 & 3,03 & 0,18 \\
\hline 5 & $\begin{array}{l}\text { Kebersihan dan } \\
\text { kenyamanan transportasi } \\
\text { yang digunakan }\end{array}$ & 0,05 & 3,02 & 0,15 \\
\hline 6 & $\begin{array}{l}\text { Proses pembelian paket } \\
\text { wisata tirtayatra ke India }\end{array}$ & 0,05 & 3,01 & 0,15 \\
\hline 7 & $\begin{array}{l}\text { Kebersihan dan kerapian } \\
\text { seragam pemandu wisata } \\
\text { dan karyawan Melati } \\
\text { Tours }\end{array}$ & 0,05 & 2,99 & 0,14 \\
\hline 8 & $\begin{array}{l}\text { Keramahan tamahan } \\
\text { karyawan di Melati Tours } \\
\text { dalam }\end{array}$ & 0,05 & 2,96 & 0,14 \\
\hline
\end{tabular}

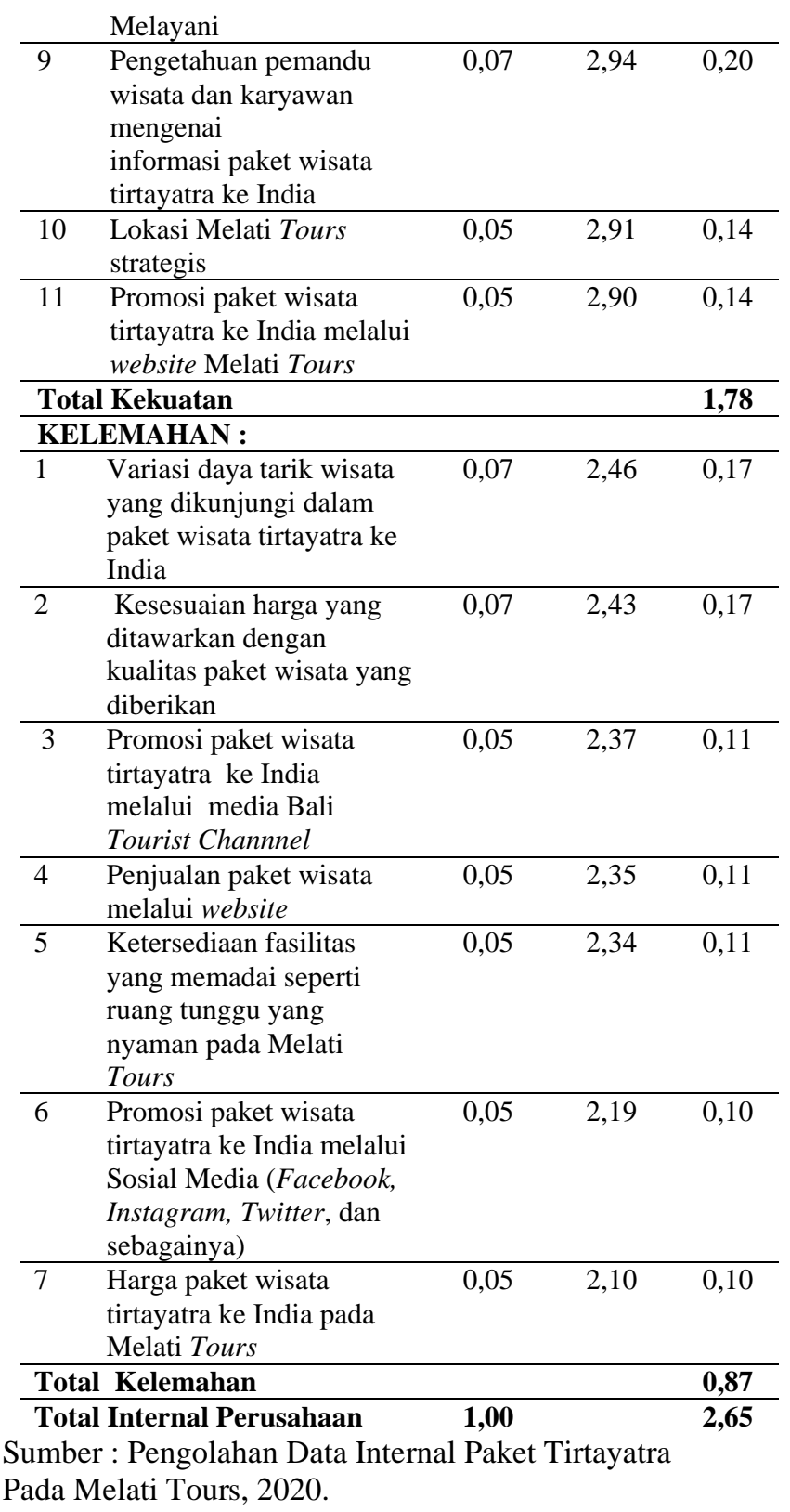

Berdasarkan hasil dari pengolahan data Bobot, Rating dan Skor (Bobot x Rating) lingkungan internal paket wisata tirtayatra ke India pada Melati Tours, dapat diketahui bahwa total internal Melati Tours adalah 1,00 dengan jumlah Skor 2,65.

Selanjutnya adalah dengan menganalisis faktor lingkungan eksternal (Eksternal Factor Analysis Summary) atau EFAS paket wisata tirtayatra ke India pada Melati Tours dari hasil kuesioner yang dibagikan kepada pemilik dan karyawan Melati Tours serta kepada 5 orang Akademisi Pariwisata yang berkompeten di bidang pemasaran, pada tabel 2 . 
Tabel 2

Bobot, Rating dan Skor EFAS Paket Wisata Tirtayatra ke India pada Melati Tours

\begin{tabular}{|c|c|c|c|}
\hline Faktor & Bobot & Rating & Skor \\
\hline \multicolumn{4}{|l|}{ Peluang } \\
\hline $\begin{array}{l}\text { 1. Adanya trend } \\
\text { tirtayatra ke } \\
\text { India yang terus } \\
\text { berkembang }\end{array}$ & 0,12 & 3,60 & 0,4 \\
\hline $\begin{array}{l}\text { 2. Kebijakan } \\
\text { pemerintah } \\
\text { dalam } \\
\text { memudahkan } \\
\text { proses } \\
\text { keberangkatan } \\
\text { ke luar negeri } \\
\text { khususnya ke } \\
\text { India } \\
\end{array}$ & 0,15 & 3,40 & 0,5 \\
\hline $\begin{array}{ll}\text { 3. } & \text { Semakin } \\
\text { banyaknya } \\
\text { BPW yang } \\
\text { menjual paket } \\
\text { wisata tirtayatra } \\
\text { ke India di Bali } \\
\end{array}$ & 0,11 & 3,20 & 0,3 \\
\hline $\begin{array}{ll}\text { 4. } & \text { Perkembangan } \\
\text { alat komunikasi }\end{array}$ & 0,11 & 3,00 & 0,3 \\
\hline $\begin{array}{ll}\text { 5. } & \text { Kemajuan } \\
\text { media internet } \\
\text { dalam } \\
\text { memasarkan } \\
\text { produk } \\
\text { tirtayatra ke } \\
\text { India } \\
\end{array}$ & 0,11 & 2,80 & 0,3 \\
\hline Total Peluang & & & 1,8 \\
\hline \multicolumn{4}{|l|}{ Ancaman } \\
\hline $\begin{array}{ll}\text { 1. } & \text { Nilai tukar } \\
\text { rupiah melemah }\end{array}$ & 0,12 & 1,60 & 0,1 \\
\hline $\begin{array}{ll}\text { 2. } & \begin{array}{l}\text { Krisis ekonomi } \\
\text { global }\end{array}\end{array}$ & 0,16 & 1,40 & 0,2 \\
\hline $\begin{array}{l}\text { 3. Semakin } \\
\text { banyaknya } \\
\text { online travel } \\
\text { agent yang } \\
\text { menjual paket } \\
\text { wisata tirtayatra } \\
\text { ke India } \\
\end{array}$ & 0,12 & 1,20 & 0,1 \\
\hline Total Ancaman & & & 0,4 \\
\hline $\begin{array}{l}\text { Total Eksternal } \\
\text { Perusahaan }\end{array}$ & 1,00 & & 2,20 \\
\hline
\end{tabular}

Sumber : Pengolahan Data Eksternal Paket Tirtayatra Pada Melati Tours, 2020

Berdasarkan hasil dari pengolahan data Bobot, Rating dan Skor (Bobot x Rating) lingkungan eksternal paket wisata tirtayatra ke India pada Melati Tours, dapat diketahui bahwa total eksternal Melati Tours adalah 1,00 dengan jumlah Skor 2,20.

\section{Matriks Internal Eksternal (IE) Paket Wisata Tirtayatra ke India pada Melati Tours}

Berdasarkan hasil yang diperoleh dari analisis IFAS EFAS maka selanjutnya dapat disusun dalam matriks internal eksternal (IE) (Rangkuti, 2013). Matriks IE digunakan untuk menganalisis posisi perusahaan secara lebih detail dan melihat strategi apa yang tepat untuk diterapkan oleh perusahaan. Hasil dari penilaian matriks IE untuk paket wisata tirtayatra ke India pada Melati Tours diperoleh hasil studi ini dalam matriks IE diperoleh hasil dari nilai total IFAS sebesar 2,65 dan nilai total EFAS sebesar 2,20 menunjukkan posisi paket wisata tirtayatra ke India pada Melati Tours yang berada pada sel VIII, sehingga diketahui posisi paket wisata tirtayatra ke India pada Melati Tours adalah Growth dan Diversifikasi Konglomerat. Dalam strategi ini, Melati Tours dalam memasarkan paket wisata tirtayatra ke India memerlukan strategi pertumbuhan melalui tekanan strategi yaitu lebih ditekankan pada sinergi finansial daripada sinergi pemasaran produk (seimbang produk dan harga).

\section{Matriks SWOT}

Matriks SWOT merupakan metode yang digunakan untuk menyusun faktor - faktor strategi perusahaan (Rangkuti, 2013). Dalam menganalisis kondisi paket wisata tirtayatra ke India pada Melati Tours berdasarkan analisis lingkungan internal yaitu sebagai Kekuatan (Strengths) dan Kelemahan (Weaknesses), serta analisis lingkungan eksternal yaitu sebagai Peluang (Opportunities) dan Ancaman (Threats) yang diperoleh dari hasil penelitian pada paket wisata tirtayatra ke India pada Melati Tours. Berdasarkan hasil studi ini, dapat diketahui strategi yang dapat diterapkan Melati Tours dalam memasarkan paket wisata tirtayatra ke India berdasarkan hasil matriks SWOT, sebagai berikut :

1. Strategi Strengths Opportunities (SO), adalah strategi yang menggunakan kekuatan dan memanfaatkan peluang yang ada. Strategi yang dapat diterapkan dalam pemasaran paket wisata tirtayatra ke India pada Melati Tours meliputi strategi penambahan produk seperti dengan penambahan komponen - komponen yang 
menarik untuk dikemas menjadi paket wisata yang ditawarkan.

2. Strategi Weaknesess Opportunities (WO), merupakan strategi meminimalkan kelemahan dan memanfaatkan peluang yang ada. Strategi yang dapat diterapkan dalam pemasaran paket wisata tirtayatra ke India pada Melati Tours adalah strategi penciptaan produk baru seperti dengan mencari referensi untuk menciptakan paket wisata spiritual yang baru untuk ditawarkan kepada wisatawan.

3. Strategi Strengths Threats (ST), merupakan strategi yang menggunakan kekuatan dan mengatasi ancaman yang ada. Strategi yang dapat diterapkan dalam pemasaran paket wisata tirtayatra ke India pada Melati Tours adalah strategi peningkatan promosi seperti dengan meningkatkan kegiatan promosi paket wisata tirtayatra secara berkala pada sosial media Melati Tours.

4. Strategi Weaknesess Threats (WT), adalah strategi yang meminimalkan kelemahan dan menghindari ancaman yang ada. Strategi yang dapat diterapkan dalam pemasaran paket wisata tirtayatra ke India pada Melati Tours adalah strategi menerapkan sistem peluang usaha seperti dengan mencari partner kerja yang dapat membantu perekonomian Melati Tours.

\section{Strategi Baru yang dapat Dilakukan Melati Tours dalam Memasarkan Paket Wisata Tirtayatra ke India}

1. Strategi Penambahan Produk

Strategi penambahan produk penting dilakukan demi dapat tetap memberikan kepuasan terhadap wisatawan yang membeli paket wisata tirtayatra ke India pada Melati Tours antara lain :

a. Menambahkan komponen - komponen yang menarik untuk dikemas menjadi paket wisata namun masih dalam konteks spiritual untuk wisatawan, seperti penambahan daya tarik wisata seperti mengunjungi Kailasanatha/Candi Kailasa (Candi tempat pemujaan Dewa Siwa) yang menurut sejarah candi ini tidak bisa dihancurkan oleh apapun dan siapapun, kemudian mengunjungi Laxminarayan Temple (Birla Mandir) yang merupakan kuil warna - warni yang terbuka untuk semua kasta dan keyakinan serta terdapat kuil Dewa
Wisnu dan Dewi Laksmi dan perayaan ulang tahun Dewa Krisna pada Bulan Agustus atau Diwali di Bulan Oktober yang merupakan acara besar ditempat tersebut, selanjutnya adalah mengunjungi Sri Ranganathaswamy Temple yaitu tempat pemujaan Ranganatha (reinkarnasi Dewa Wisnu) yang merupakan tempat sakral yang dihiasi 21 warna gopurams/menara, beberapa lukisan dinding, 50 tempat pemujaan, 9 Kolam Suci dan Aula yang mempunyai seribu pilar, kemudian adalah mengikuti upacara Kumbh Mela (perayaan umat Hindu di India dengan mengambil air dan membasuh diri yang dilakukan di tiga Sungai Suci India) yang dipercaya untuk menghapus dosa dan mencapai keabadian pada Sungai Gangga, Sungai Yamuna dan Sungai Saraswati. Daya tarik wisata tersebut dapat ditambahkan kedalam paket wisata tirtayatra ke India pada Melati Tours yang sebelumnya tidak ada, sehingga wisatawan tertarik untuk membeli paket wisata tirtayatra ke India pada Melati Tours.

b. Kerjasama dengan pelaku usaha yang ada di tempat yang dikunjungi guna memudahkan dalam mendapatkan informasi dan referensi terkait daya tarik wisata maupun atraksi wisata spritual yang ada di tempat tersebut sehingga Melati Tours dapat menciptakan produk wisata yang baru sehingga menjadi benefit untuk kedepannya.

c. Meningkatkan promosi paket wisata tirtayatra dengan cara bekerjasama dengan penyiaran TV swasta untuk mempromosikan paket wisata yang dipasarkan Melati Tours secara berkala serta dengan meningkatkan promosi melalui sosial media seperti membuat penawaran menarik mengenai paket wisata tirtayatra ke India pada akun facebook, instragram dan website dengan menyertakan foto dokumentasi daya tarik wisata yang akan dikunjungi dengan gambaran suasana didalamnya.

2. Strategi Penciptaan Produk Baru

Strategi penciptaan produk baru penting dilakukan untuk memberikan wisatawan 
paket wisata yang belum pernah diikutinya, antara lain :

a. Mencari referensi dalam menciptakan paket wisata yang unik dan menarik serta memiliki ciri khas tersendiri sebagai paket wisata spiritual dengan cara mencari informasi pada buku panduan perjalanan wisata maupun kajian pustaka yang relevan sebagai acuan mengenai apa saja yang diinginkan wisatawan dan hal apa saja yang menjadi trend saat ini yang kemudian dipadukan menjadi paket wisata spiritual seperti ikut serta dalam event keagamaan ditempat yang dikunjungi sehingga memiliki ciri khas tersendiri dari paket wisata spiritual yang ditawarkan Melati Tours yang tidak terdapat pada BPW maupun online travel agent lain.

b. Memanfaatkan kemajuan IPTEK dalam inovasi produk baru dengan cara mencari informasi melalui internet, artikel dan sosial media mengenai produk wisata spiritual yang banyak diminati wisatawan sehingga bisa dipadukan dengan paket wisata yang dipasarkan Melati Tours sehingga terciptanya paket wisata baru seperti paket wisata yang lebih ditekankan pada keikutsertaan dalam suatu upacara keagamaan bukan hanya sekedar mengunjunginya.

3. Strategi Pengembangan Promosi

Strategi pengembangan promosi penting dilakukan untuk memperkenalkan dan memasarkan paket wisata tirtayatra ke India pada Melati Tours kepada wisatawan antara lain :

a. Peningkatan promosi paket wisata tirtayatra ke India pada Melati Tours melalui media cetak dengan cara membuat iklan pada koran yang berisikan paket wisata tirtayatra ke India dengan desain yang menarik agar wisatawan tertarik untuk membelinya.

b. Meningkatkan promosi paket wisata tirtayatra ke India pada Melati Tours melalui media elektronik dengan cara memperluas kerjasama dengan penyiaran TV swasta dalam mempromosikan paket wisata tirtayatra ke India pada Melati Tours secara berkala. Diharapkan dengan adanya promosi paket wisata tirtayatra ke India pada Melati Tours melalui media TV dapat menjangkau lebih banyak wisatawan.

c. Peningkatan promosi paket wisata tirtayatra ke India pada sosial media Melati Tours dengan cara melakukan promosi paket tirtayatra ke India pada Melati Tours secara berkala melalui akun facebook, instagram dan sebagainya yang berisikan mengenai kejelasan paket wisata tirtayatra ke India dengan lebih detail dengan penawaran harga yang ditawarkan sehingga diharapkan dapat membuat wisatawan mengetahui detail paket wisata tirtayatra ke India yang disediakan oleh Melati Tours.

4. Strategi Menerapkan Sistem Peluang Usaha

Strategi menerapkan sistem peluang usaha penting dilakukan demi keberlangsungan usaha atau bisnis yang dijalani Melati Tours dalam memasarkan paket wisata tirtayatra ke India, yaitu Melati Tours menjual paket wisata tirtayatra ke India kepada Online Travel Agent ataupun Agent lainnya yang juga menjual paket wisata untuk membantu Melati Tours dalam menjual paket wisata tirtayatra ke India, selanjutnya adalah Melati Tours membagi sebagian keuntungan penjualan paket wisata tersebut untuk Agent yang berhasil membantu menjual paket wisata tirtayatra yang dirancang oleh Melati Tours.

\section{SIMPULAN DAN SARAN \\ Simpulan}

Indikator - indikator internal yang menjadi kekuatan dari Melati Tours dalam memasarkan paket wisata tirtayatra ke India adalah (1) Kebersihan kantor Melati Tours (2) Proses memberikan informasi yang lengkap mengenai paket wisata tirtayatra ke India (3) Pelayanan pemandu wisata dalam kegiatan tirtayatra ke India (4) Promosi melalui penawaran menarik/potongan harga pada paket wisata tirtayatra ke India pada Melati Tours (5) Kebersihan dan kenyamanan transportasi yang digunakan (6) Proses pembelian paket wisata tirtayatra ke India (7) Kebersihan dan kerapian seragam pemandu wisata dan karyawam Melati Tours (8) Keramahan tamahan karyawan di Melati Tours dalam melayani (9) Pengetahuan 
pemandu wisata dan karyawan mengenai informasi paket wisata tirtayatra ke India pada Melati Tours (10) Lokasi Melati Tours strategis (11) Promosi paket wisata tirtayatra ke India melalui website Melati Tours. Sedangkan indikator - indikator yang menjadi kelemahan Melati Tours dalam memasarkan paket wisata tirtayatra ke India adalah (1) Variasi daya tarik wisata yang dikunjungi dalam paket wisata tirtayatra ke India (2) Kesesuaian harga yang ditawarkan dengan kualitas paket wisata yang diberikan (3) Promosi paket wisata tirtayatra ke India melalui media Bali Tourist Channnel (4) Penjualan paket wisata melalui website (5) Ketersediaan fasilitas yang memadai seperti ruang tunggu yang nyaman pada Melati Tours (6) Promosi paket wisata tirtayatra ke India melalui Sosial Media (Facebook, Instagram, Twitter, dan sebagainya) (7) Harga paket wisata tirtayatra ke India pada Melati Tours.

Indikator - indikator eksternal yang menjadi peluang Melati Tours dalam memasarkan paket wisata tirtayatra ke India adalah (1) Adanya trend tirtayatra ke India yang terus berkembang (2) Kebijakan pemerintah dalam memudahkan proses keberangkatan ke luar negeri khususnya ke India (3) Semakin banyaknya BPW yang menjual paket wisata tirtayatra ke India di Bali (4) Perkembangan alat komunikasi (5) Kemajuan media internet dalam memasarkan paket wisata tirtayatra ke India. Sedangkan indikator - indikator yang menjadi ancaman Melati Tours dalam memasarkan paket wisata tirtayatra ke India adalah (1) Nilai tukar rupiah melemah (2) Krisis ekonomi global (3) Semakin banyaknya online travel agent yang menjual paket wisata tirtayatra ke India.

Strategi pemasaran yang dapat dilakukan Melati Tours dalam memasarkan paket wisata tirtayatra ke India adalah (1) Strategi penambahan produk (2) Strategi penciptaan produk baru (3) Strategi peningkatan promosi (4) Strategi menerapkan sistem peluang usaha. telah dipasarkan Melati Tours guna meningkatkan penjualan paket wisata tirtayatra ke India pada Melati Tours.

Melati Tours harus menciptakan inovasi baru dalam menciptakan paket wisata spriritual/tirtayatra yang baru seperti keikutsertaan wisatawan dalam mengikuti event keagamaan yang ada dalam paket wisata tirtayatra ke India yang belum dikemas sebelumnya pada paket wisata tirtayatra ke India pada Melati Tours.

Melati Tours harus meningkatkan promosi paket wisata tirtayatra ke India seperti peningkatan promosi pada media cetak seperti koran, melalui media elektronik seperti bekerjasama dengan penyiaran TV swasta serta peningkatan promosi melalui media online pada media sosial media yang dimiliki Melati Tours untuk membantu penjualan paket wisata tirtayatra ke India pada Melati Tours.

Melati Tours harus menjalin kerjasama dengan online travel agent lain dalam membantu tingkat penjualan paket wisata tirtyatra ke India.

\section{Saran}

Melati Tours harus melakukan penambahan produk dalam paket wisata tirtayatra ke India yang memiliki ciri khas seperti mengunjungi daya tarik wisata yang menarik di India yang belum dikemas sebelumnya pada paket wisata tirtayatra yang 


\section{Kepustakaan}

Kusmayadi, 2004. "Statistika Pariwisata Deskriptif". Jakarta : PT. Gramedia Pustaka Utama.

Pendit, Nyoman S. 1994. "Pengertian Wisata Spiritual”. Jakarta : Pradnya Paramita.

Rangkuti, 2013. "Analisis SWOT Teknik Membedah Kasus Bisnis”. Jakarta PT. Gramedia Pustaka Utama.

Soethama, 2011. "Perkembangan Pariwisata di Bali”. Sosiologi Pariwisata. Yogyakarta : Andi.

Yoeti, Oka A. 1985. "Wisata Spiritual". Pengantar Ilmu Pariwisata. Bandung : Angkasa. 